\title{
Why Union Law Can and Should Protect Stateless Persons
}

\author{
Katja Swider \\ Doctoral researcher at the Amsterdam Center for European Law and \\ Governance, University of Amsterdam \\ k.j.swider@uva.nl \\ Maarten den Heijer \\ Assistant Professor of International Law at the University of Amsterdam, \\ the Netherlands \\ m.denheijer@uva.nl
}

\begin{abstract}
This contribution argues that the European Union can and should establish a legal framework for the identification and protection of stateless persons who reside in one of the Member States. Our proposal for EU legislative action is based on the worrying observation that the post-war international legal framework for protecting stateless persons has failed to take root in a majority of EU Member States. This contribution analyses the potential of the $\mathrm{EU}$ to address protection failures stemming from legislative inactivity of Member States. We argue that the EU is competent to address the issue and that EU action need not conflict with Member States' prerogatives in nationality
\end{abstract}

* Katja Swider's PhD research on statelessness receives funding from the Netherlands Organisation for Scientific Research (Nwo). This contribution compiles and builds on: K. Swider Protection and Identification of Stateless Persons Through Eu Law, Amsterdam Centre for European Law and Governance Research Paper No. 2014-05, July 2014; a note on the same topic published by the Meijers Committee of which Maarten den Heijer was the lead author: Commissie Meijers, Proposal for an EU directive on the identification and the protection of stateless persons, См 1410, 13 October 2014, available at http://www.commissie-meijers.nl/; and a report for the European Parliament co-authored by Katja Swider: Practices and Approaches in EU Member States to Prevent and End Statelessness, Study for the LiBE Committee, Nov. 2015. The authors would like to thank Gerard-René de Groot, Leonard Besselink and Inge Sturkenboom (UNHCR) for their helpful comments on an earlier draft.

(C) KATJA SWIDER AND MAARTEN DEN HEIJER, 2017 | DOI 10.1163/15718166-12340004

This is an open access article distributed under the terms of the prevailing CC-BY-NC license at the time of publication. 
matters. The key elements of an EU directive on statelessness would consist of common criteria for i) a fair procedure for determining whether a person is stateless; ii) the standard of treatment to be accorded to stateless persons; and iii) the conditions of residence for stateless persons.

\section{Keywords}

Statelessness - EU - legislative competence - protection - status determination human rights

\section{1 \\ Introduction}

Problems arising from statelessness have long been overlooked in Europe on both the national and supranational level. But this is changing. Statelessness features more prominently on the agenda of intergovernmental institutions in Europe, and several governments in Europe have established or are in the process of putting into place mechanisms that specifically address the plight of stateless persons. ${ }^{1}$ In 2014, UNHCR published its Handbook on Protection of Stateless Persons, which replaced three guidelines that had been published in 2012, with a view to promoting the development and implementation of law and policies relating to the protection of stateless persons. ${ }^{2}$ In December 2015, the Council of Ministers of the EU adopted its first conclusions on statelessness, in which it acknowledged the importance of identifying stateless persons and strengthening their protection. ${ }^{3}$

Despite growing European and international attention for statelessness, the debate on the formulation of actual solutions in the sphere of reducing statelessness and protecting stateless persons has until now been chiefly situated at the national level. From a legal perspective, this seems only appropriate,

1 European Parliament resolution of 14 January 2009 on the situation of fundamental rights in the European Union 2004-2008 (2007/2145(INI)); Muižnieks, Nils, Stateless but not rightless: improving the protection of stateless persons in Europe, 8 April 2014, Council of Europe Commissioner for Human Rights, CommDH/Speech (2014) 6; Council of Europe Parliamentary Assembly Resolution 1989 (2014) of 9 April 2014, 'Access to nationality and the effective implementation of the European Convention on Nationality'.

2 UNHCR, Handbook on Protection of Stateless Persons (Geneva, UNHCR, 2014).

3 Conclusions of the Council and the Representatives of the Governments of the Member States on Statelessness, 4 December 2015, doc. 893/15. 
as States have committed themselves to taking action under the UN treaties on statelessness. It is incumbent on them to transpose the relevant international obligations into national laws and policies. The EU Council conclusions underline, furthermore, that the acquisition of nationality falls within the competence of Member States and they do not go further than calling for the exchange of good practices among Member States. In this contribution, we make the argument, however, that the European Union, which itself is not a party to any treaty dealing with statelessness, can and should establish a common legal framework for identifying and protecting stateless persons. That argument rests on two pillars.

First, studies indicate that dedicated protection mechanisms for stateless persons are lacking in most EU Member States and that several Member States violate international standards regarding protection against statelessness. ${ }^{4}$ In Member States where identification or protection frameworks are in place, their accessibility and functioning is subject to criticism. ${ }^{5}$ The formulation of binding rules at the level of the European Union has the potential to contribute to the full and inclusive application by Member States of the 1954 Convention relating to the Status of Stateless Persons (hereafter: the 1954 Convention). Minimum standards for identifying and protecting stateless persons set by the European Union would promote a common approach to such issues as the interpretation of the definition of stateless person, the functioning of identification procedures and the content of protection. They would contribute to guaranteeing that stateless persons residing in a Member State have access to meaningful protection.

Second, the common immigration policy of the European Union is premised on the idea that the conditions for admission and residence of third country nationals must be approximated. As a matter of Union law, stateless persons are equated with third-country nationals (Art. 67(2) TFEU). A failure to regulate the status of stateless persons at the level of the European Union would result in stateless persons being left out in the EU's immigration policy.

4 Groot, G.R. de, K. Swider, O.Vonk, Practices and Approaches in EU Member States to Prevent and End Statelessness, Study for the LiBe Committee, Nov. 2015 (Brussels, European Parliament, 2015), p. 42, 53; Manly, M., 'UNHCR's Mandate and Activities to Address Statelessness in Europe', 14 European Journal of Migration and Law (2012) 274-275; Waas, L. van, 'Statelessness: A 21st Century Challenge for Europe', 2 Security and Human Rights (2009) 137-141.

5 See, for example, the criticism on the French determination procedure Chassin, C.-A., 'Panorama français du droit de l'apatridie', 2 Revue française de droit administratif (2003) 324-330; Likibi, R., Le droit de l'apatridie: pratiques et controverses (Paris, Publibook, 2013), pp. 257-303. The Belgian system of determination through courts also has drawbacks, see UNHCR, Mapping Statelessness in Belgium (Geneva, UNHCR, 2012), pp. 47-63. 
This runs counter to the very objective of establishing common approaches to questions of admission and residence of third-country nationals. From the EU's perspective, it would be only natural to harmonize the conditions under which stateless persons, similar to other categories of third-country nationals, can participate in the Union-wide area of free movement.

The potential benefits of EU-wide action on statelessness are from time to time pointed out by academics and international and non-governmental organizations. ${ }^{6}$ In 2005, a UNHCR study on the implementation of the 1954 Convention in EU Member States mentioned a number of areas related to the protection of stateless persons that could benefit from EU harmonization. ${ }^{7}$ These included identification mechanisms, conditions for permitting lawful stay, mutual recognition of determinations on statelessness and the treatment to be accorded to stateless persons. There has been, however, no follow-up on these recommendations on the EU level, and UNHCR also seems to have stopped pursuing the issue. ${ }^{8}$ More recent academic publications advocate softlaw EU measures on statelessness, assuming that there is no EU competence to pass relevant legislation. ${ }^{9}$ We take issue with that assumption, and will explain why an EU instrument on statelessness respects the division of competences between the EU and its Member States, why it meets the principle of subsidiarity, and what the EU Treaty basis for such an instrument can be.

6 Gyulai, G., 'Statelessness in the EU Framework for International protection', 14 European Journal of Migration and Law (2012) 284, 294-295; Molnar, T., 'Stateless Persons under International Law and EU Law: a Comparative Analysis Concerning their Legal Status, with Particular Attention to the Added Value of the EU Legal Order', $5^{1}$ Acta Juridica Hungarica (2010) 303; Waas, L. van, 'EU Citizenship for Stateless People?', European Network on Statelessness Blog (5 November 2013), www.statelessness.eu/blog/eu-citizenship-stateless-people; Groot, G.R. de, K. Swider, O. Vonk, Practices and Approaches in EU Member States to Prevent and End Statelessness, Study for the LibE Committee, Nov. 2015 (Brussels, European Parliament, 2015), pp. 54-59.

7 Batchelor, C., 'The 1954 Convention Relating to the Status of Stateless Persons: Implementation Within the European Union Member States and Recommendations for Harmonization', 22(2) Refuge (2005) 31-58.

8 In its 2015 recommendations to the EU presidency, UNHCR did call for attention to end statelessness, but stopped short of recommending EU legislative action: UNHCR's recommendations to Luxembourg and the Netherlands for the EU Presidency, July 2015.

9 Gyulai, G., 'Statelessness in the EU Framework for International protection', 14 European Journal of Migration and Law (2012) 284, 294-295; Molnar, T., 'Stateless Persons under International Law and EU Law: a Comparative Analysis Concerning their Legal Status, with Particular Attention to the Added Value of the EU Legal Order', $5_{1}$ Acta Juridica Hungarica (2010) 303 . 
We want to stress that our proposal for Eu legislative action is both modest and realistic in scope. It respects, first, the division of competences between the EU and the Member States. It only focuses on the identification and protection of stateless persons and accordingly does not intervene in Member States' prerogatives in the field of determining who its nationals are. Second, the primary aim of our proposal for EU legislative action lies in consolidating, modernizing and effectuating the obligations that are already incumbent on a majority of EU Member States by virtue of the 1954 Convention. In working out these international obligations, we draw on existing practices in several EU Member States and the guiding work of UNHCR. Third, we discuss only the legal position of stateless persons de jure, i.e. persons without a nationality, and do not engage with statelessness de facto-a term which most commonly refers to persons without an effective nationality. Although de facto statelessness raises many issues worth addressing, we deem it wise not to conflate the two categories as they require separate legal solutions. ${ }^{10}$ Fourth, it transpires from experiences in States that do operate meaningful protection mechanisms that fears of such mechanisms attracting large numbers of stateless persons must generally be considered to be unfounded. ${ }^{11}$

By way of background to our proposal, we first summarize the obligations of States towards stateless persons under international law, thereby identifying a number of protection gaps and issues related to interpretation and implementation (section 2). Next, a few general observations are made on the predicament of stateless persons in Europe-in terms of numbers and categories of stateless persons as well as identifiable common failures in protecting stateless persons (section 3). Sections 4 and 5 explain the potential of the European Union in addressing these failures, taking into account the division of competences between the EU and the Member States and discussing what the legal basis of an EU legislative instrument should be. On the basis of this analysis, section 6 outlines the key legal elements of our proposal, namely the setting of common criteria for i) a fair procedure for determining whether a person is stateless; ii) the standard of treatment to be accorded to stateless persons; and iii) the conditions of residence for stateless persons.

Our proposal is based on the worrying observation that the post-war international legal regime for protecting stateless persons has failed to take root in many European countries. In practice, many stateless persons do not have procedural rights to have their status determined and the absence in many States of a route by which stateless persons can regularize their status leaves them at

\footnotetext{
10 See below, section 2.

11 See for data section $3 \cdot 3$.
} 
risk of permanent marginalization. This contrasts sharply with the existence of asylum determination procedures and protected statuses in all EU Member States which give effect to the 1951 Refugee Convention and which are consolidated in the common EU asylum policy. There are obviously severe strains on that policy at this moment, but those are caused by factors which are unlikely to surface in the context of statelessness. The challenges of burden sharing and sudden influx are not central to the statelessness issue and do not affect our proposal.

\section{International Standards on Statelessness}

International legal norms on statelessness can be roughly divided into two categories: the 'avoidance norms' and the 'protection norms'. The major UN treaty that enshrines the 'avoidance norms' is the 1961 Convention on the Reduction of Statelessness (hereafter 1961 Convention), which has 63 State Parties, of which 19 are EU Member States. ${ }^{12}$ This Convention establishes standards on the acquisition and loss of nationality, with the aim of preventing statelessness from occurring. Other international and regional treaties also contain avoidance norms, such as the Convention on the Rights of the Child, the Convention on the Elimination of all forms of Discrimination against Women and the European Convention on Nationality. ${ }^{13}$ International norms on the avoidance of statelessness are highly instrumental in ensuring that more people have access to a nationality of a State with which they have a relevant link. However, they stop short of guaranteeing that every person has a nationality, even if they would be subscribed to and implemented universally. They allow for exceptions through which states can acquiesce in statelessness arising at birth or from withdrawal of nationality. ${ }^{14}$

As a matter of reality therefore, and notwithstanding the laudable campaign launched by UNHCR in 2014 to eradicate statelessness by $2024,{ }^{15}$ it is to be accepted that statelessness will continue to occur. It follows that stateless

\footnotetext{
12 As of July 2016.

13 Art. 7(2) of the UN Convention on the Rights of the Child of 1989; Art. 9(1) CEDAw; Art. $6(2 \mathrm{~b})$ of the European Convention on Nationality. Also see Art. 18 of the UN Convention on the Rights of Persons with Disabilities of 2006 and Art. 5(d)(iii) of the International Convention on the Elimination of All Forms of Racial Discrimination of 1965 .

14 See e.g. Arts 1(2)(b), 7(4) and 8(2-4) of the 1961 Convention.

15 UNHCR, 'Global Action Plan to End Statelessness, 2014-2024', November 2014.
} 
persons need legal mechanisms that enable them to build their lives without a nationality.

This is exactly the purpose of the 'protection norms' on statelessness that were developed in the 1954 Convention. The 1954 Convention guarantees a variety of rights for stateless persons who find themselves under the jurisdiction of a State Party. Some of these rights are guaranteed to any stateless person who is present on the territory of a State Party, such as the right to identity documents, ${ }^{16}$ the right of access to courts, ${ }^{17}$ and the right to primary education. ${ }^{18}$ The enjoyment of other rights is dependent on whether the person has legal residence or whether the State Party is his or her place of habitual residence. ${ }^{19}$ These concern inter alia the right to work (Art. 17), the right to social security benefits (Art. 24) and the right to obtain travel documents (Art. 28). Access to other rights may be made conditional on the same requirements as applied to foreigners generally, ${ }^{20}$ for example the right to move freely within the territory of the state (Art. 26). And some rights need to be provided on par with nationals, such as the freedom of religion (Art. 4).

The 1954 Convention leaves a number of issues unsettled however, which helps explaining why the treatment of stateless persons varies considerably amongst State Parties.

The first issue concerns the interpretation of certain terms in the definition of 'stateless person' in the 1954 Convention. Article 1(1) of the Convention defines a stateless person as anyone 'who is not considered as a national by any State under the operation of its law'. It is a negatively formulated definition, describing statelessness in terms of absence of the legal status of nationality. One interpretative matter concerns the words 'any State', begging the question to how many countries an inquiry into statelessness must extend to. As it will be virtually impossible to prove with absolute certainty that one is not a national of any State in the world, UNHCR suggests that an inquiry can be limited to the State or States with which a person has a relevant link, such as being born there or having formerly enjoyed habitual residence there. ${ }^{21}$ Another

\footnotetext{
16 Art. 271954 Convention.

17 Art. 161954 Convention.

18 Art. 221954 Convention.

19 See UNHCr, Handbook on Protection of Stateless Persons (Geneva, UNHCR, 2014), para 132-139.

20 State Parties cannot place such requirements on stateless persons which the latter are unable to comply with those due to their statelessness, see Art. 6 of the 1954 Convention.

21 See, on the definition of a stateless person: UNHCR, Handbook on Protection of Stateless Persons (Geneva, UNHCR, 2014), para 13-56.
} 
interpretative difficulty is the question of what types of political entities should be considered as a 'State' for the purposes of satisfying the definition, and whether it includes failed States, for example, or States that may not have been recognised by a State party. ${ }^{22}$ Especially liable to divergent interpretation, further, is the condition that a person is 'not considered as a national [...] under the operation of [...] law'. It is obvious that substantiating statelessness can involve serious evidentiary challenges, precisely because statelessness is often not documented. Normally, it will require probing into how a State applies its nationality laws and possible decisions taken in respect of the individual. But how far this investigative duty stretches, and whether, for example, States are also required to engage in dialogue with the other States in order to determine how the laws are interpreted and applied, is not specified in the Convention. Disparities in state practice exist in spheres such as the standard of proof and the burden of proof in producing documentary evidence. ${ }^{23}$ State Parties also have diverging practices on the question whether individuals who voluntarily renounce their nationality should be considered stateless. ${ }^{24}$

It is important to note that in the definition of a stateless person of the 1954 Convention, such factors as the migration status of the individual or his ability to access basic rights do not play a role. Some authors, by invoking the socalled concept of 'de-facto' statelessness, broaden this definition to include persons without legal residence, who cannot be deported or who lack access to some basic rights, even if another State considers them as nationals. ${ }^{25}$ We believe that even though statelessness is closely linked to the legal vulnerability of undocumented migrants and their discrimination and exploitation, these concepts cannot be conflated, and require separate legal solutions. Not all undocumented migrants are stateless, and not all stateless persons are undocumented migrants. We therefore focus on statelessness in the legal

This holds for people who are considered as nationals by entities that do not enjoy universal recognition as states, such as Taiwan or Palestine.

23 Batchelor, C., 'The 1954 Convention Relating to the Status of Stateless Persons: Implementation Within the European Union Member States and Recommendations for Harmonization', 22(2) Refuge (2005) 40. Also see UNHCR, Handbook on Protection of Stateless Persons (Geneva, UNHCR, 2014), para 87-93.

24 More extensively: UNHCR, Handbook on Protection of Stateless Persons (Geneva, UNHCR, 2014), para 51; Chassin, C.-A., 'Panorama français du droit de l'apatridie', 2 Revue française de droit administratif (2003) 324-330.

25 See, for example Sawyer, C. \& B.K. Blitz (eds), Statelessness in the European Union: Displaced, Undocumented, Unwanted (Cambridge, Cambridge University Press, 2011); Busser, A. \& P.R. Rodrigues, 'Staatloze Roma in Nederland', 8 Asiel-en Migrantenrecht (2010) 384-390. 
meaning of not being recognised as a national by any state under the operation of its law, as defined in the 1954 Convention.

A second concern is that neither of the two Un Statelessness Conventions place an explicit obligation on Contracting States to establish a statelessness determination procedure. The identification of stateless persons has only recently been recognised by the UN as an issue requiring separate attention. ${ }^{26}$ It is widely agreed that it is impossible to effectively implement many of the provisions of these Conventions without having a mechanism for the identification of their beneficiaries. By analogy, the 1951 Refugee Convention neither contains an explicit obligation to establish a refugee determination procedure, but the implicit duty to do so has been recognised for decades already. ${ }^{27}$

A third issue is that the 1954 Convention, similar to the 1951 Refugee Convention, does not entail a right of entry or residence. The starting point for the treatment of stateless persons is Art. 7(1), which stipulates that stateless persons are to be treated as aliens generally, unless the Convention states otherwise. Therefore, the 1954 Convention does not place stateless persons in a more favourable position than aliens generally in respect of immigration rules. Almost all States operating a statelessness determination procedure, however, provide for residence based on recognition as a stateless person. ${ }^{28}$ In States without such a procedure, stateless persons may receive permission to stay on humanitarian grounds, often disconnected from a formal determination of statelessness. ${ }^{29}$ The UNHCR Handbook on the Protection of Stateless Persons suggests that many of the rights guaranteed to stateless persons in the 1954 Convention can be realised most effectively through granting them a legal residence status. ${ }^{30}$ Indeed, legal residence is in most countries a prerequisite for

26 UNHCR, Conclusion on Identification, Prevention and Reduction of Statelessness and Protection of Stateless Persons, 6 October 2006, No. 106 (LVII).

27 See, for example, 1979 UNHCR, Handbook on Procedures and Criteria for Determining Refugee Status under the 1951 Convention and the 1967 Protocol relating to the Status of Refugees, as re-edited in January 1992, HCR/IP/4/Eng/REV.1, (Geneva, UNHCR, 1992), in particular para. 189 .

28 Belgium is an exception. See, European Network on Statelessness (ENS), Statelessness Determination and the Protection Status of Stateless Persons: A summary guide of good practices and factors to consider when designing national determination and protection mechanisms (London, ENS, 2013), p. 36.

29 Batchelor, C., 'The 1954 Convention Relating to the Status of Stateless Persons: Implementation Within the European Union Member States and Recommendations for Harmonization', 22(2) Refuge (2005) 44.

30 UNHCR, Handbook on Protection of Stateless Persons (Geneva, UnHCR, 2014), paras. 147-150. 
the enjoyment of political or full socioeconomic rights, including some of the rights laid down in the 1954 Convention. It is clear, however, that State Parties to the 1954 Convention enjoy discretion in granting legal residence to stateless persons, and can set reasonable conditions on access to residence.

A fourth issue with the 1954 Convention is that the catalogue of rights to be accorded to stateless persons is outdated - and outmatched by human rights treaties of general character, such as the ICCPR, the ICESCR and the ECHR. The construction used in the Convention to incrementally increase the level of rights based on the legal bond of the stateless person with the State runs counter to the basic tenet in human rights treaties and doctrine that fundamental rights are inherent in every human being regardless of legal or personal status. The same applies to the Convention equating the required level of treatment to that of either nationals or aliens generally. For example, the 1954 Convention requires freedom of religion and the right to education to be granted to stateless persons on par with nationals (Arts. 4 and 22); and the freedom of association is to be guaranteed on par with aliens generally (Art. 15). In some respects, the rights of the 1954 Convention remain salient however, especially those rights which see specifically to the experience of stateless persons and which cannot be found in other treaties, such as the provision on personal status (Art. 12), the right to administrative assistance (Art. 25), the right to identity papers (Art. 27) and the right to travel documents (Art. 28).

Fifth, and finally, there are gaps in the treaty-based supervision framework. Contrary to the 1951 Refugee Convention, the 1954 Convention contains no provision on a supervisory body. ${ }^{31}$ In the 1961 Convention, Article 11 refers to the establishment of 'a body to which a person claiming the benefit of this Convention may apply for the examination of his claim and for assistance in presenting it to the appropriate authority'. The inclusion of this provision was deemed important, for stateless persons would normally not be able to count on a State to take up their cause in their relation with other States and they would not have the financial resources or expertise to bring legal actions on their right to be granted the nationality of a State. ${ }^{32} \mathrm{~A}$ proposal to also set up a tribunal which would be competent to decide any disputes between parties as well as to hear complaints presented by the agency on behalf of stateless

31 Cf. Art. 35 Refugee Convention. It appears that the matter of creating a supervisory body for stateless persons was for procedural reasons and for failure to raise the issue, never discussed during the Convention's drafting: Batchelor, C.A., 'Stateless Persons: Some Gaps in International Protection', 7 International Journal of Refugee Law (1995) $232 \mathrm{ff}$ at 247. 
persons was discussed during the drafting of the 1961 Convention but defeated. ${ }^{33}$ It was later decided that UNHCR would be the agency referred to in Article 11 and through a series of resolutions from 1994 onwards, the UN General Assembly gave UNHCR the formal mandate to prevent and reduce statelessness as well to protect the rights of stateless persons. ${ }^{34}$

In spite of the text and purpose of Article 11 of the 1961 Convention, however, UNHCR does not, or at least not routinely, act as an intermediary between stateless persons and States. UNHCR describes its mandate in respect of stateless persons in terms much similar as the organisation of its supervisory tasks in relation to the 1951 Refugee Convention-focussing on the gathering of information, promoting ratification, supporting legislative changes and providing guidelines on the proper application of international norms. ${ }^{35}$ One should, of course, not underestimate the potential of this work and much may indeed be expected of the publication in 2014 of the Handbook on Protection of Stateless Persons which was modelled on the highly influential Handbook on Procedures and Criteria for Determining Refugee Status. Yet, UNHCR does not itself provide 'surrogate' protection to individuals (in lieu of a country of nationality) and does not have the legal power to hear individual complaints or to enforce compliance in the case of a breach of the statelessness conventions. ${ }^{36}$ In sum, UNHC R depends on the willingness of States to achieve the aims as set out in its mandate.

It is not straightforward to draw an accurate picture of the scope and character of the statelessness phenomenon in Europe. Helpful, is that in the past five years UNHCR has commissioned a number of extensive research projects in selected European countries aimed at analysing the problem of statelessness

33 Ibid., at $25^{2-253}$.

34 Unga Res. 3274 (XXIX) of 10 Dec. 1974; Unga Res. 31/36 of 30. Nov. 1976; Unga Res. 49/169 of 23 Dec. 1994, Un Doc. A/RES/49/169; Unga Res. 50/152 of 9 Feb. 1996, un Doc. A/ RES/50/152; UNGA Res. 55/153 of 30 Jan. 2001, UN Doc. A/RES/55/153; UNGA Res. 61/137 of 25 Jan. 2007, Un Doc. A/REs/61/137.

35 The protection mandate is comprehensively described in UNHCR EXCOM Conclusion No. 106 (LVII) of 6 Oct. 2006.

36 Manly notes that UNHCR is increasingly active in some European countries, especially in the Balkans, to provide legal aid to individuals in nationality procedures: Manly, M.,'UNHCR's Mandate and Activities to Address Statelessness in Europe', 14 European Journal of Migration and Law (2012) at 272-273. 
in this part of the world. ${ }^{37}$ We deem it useful for the purposes of explaining the added value of an $\mathrm{EU}$ instrument on statelessness, to make a few brief observations about the magnitude of the statelessness problem in Europe-both in terms of numbers and categories as well as some common protection failures on the part of EU Member States.

\subsection{Statistical Information on the EU's Stateless Population}

One of UNHCR's main findings is that if any statistics on statelessness are at all gathered by state authorities of European countries, the numbers are often not representative of the real scope of the phenomenon. ${ }^{38}$ In its most recent documents, UNHCR presents the figure of 400,000 stateless persons living in the EU. ${ }^{39}$ The vast majority of this number, based on solid figures, are in Estonia and Latvia. But outside those countries, numbers usually come from national databases, which are often compiled in the context of absent or inadequate determination procedures. A cursory inquiry into national data reveals that they may not reflect reality. The Netherlands, for example, has reported to have 1,951 stateless persons in 2013, which is the number registered in the Dutch Basic Registry of Persons ('Basisregistratie Personen'). Research shows, however, that the registration of stateless persons in the Dutch Registry is often incorrect. ${ }^{40}$ The high standard of proof required to demonstrate statelessness and other problems with this registration system, is likely to result in stateless persons being registered with the status 'nationality unknown', or even with a nationality which they in fact do not possess. On the other hand, some individuals registered as stateless in the Dutch Registry may in fact possess a nationality. There are over 80,000 persons in the Netherlands with an 'unknown

37 These include Netherlands, Belgium, the uk, Malta, Finland. See Mapping Statelessness reports by the UNHCR in these countries, available on Refworld Statelessness website www.refworld.org/statelessness.html.

38 UNCHR, Mapping Statelessness in the Netherlands (Geneva, UNHCR, 2011), p. 33; UNHCR, Mapping Statelessness in Malta (Geneva, UNHCR, 2014), pp. 46-56; UNHCR, Mapping Statelessness in Belgium (Geneva, UNHCR, 2012), p. 17. See also Institute on Statelessness and Inclusion 'The World's Stateless' December 2014.

See, for example, UNHCR, 'Stateless and voiceless in the EU', Statement on the occasion of the European elections, 22 May 2014, available online at http://www.unhcr.org/537dfb209 .pdf.

UNHCR, Mapping Statelessness in the Netherlands (Geneva, UNHCR, 2011), pp. 17-18; Swider, K., Statelessness Determination in the Netherlands, Research Paper No. 2014-04 of 8 May 2014 (Amsterdam, Centre for European Law and Governance, 2014). 
nationality,41 a figure which does not make its way into the UNHCR statistics. Moreover, none of these figures account for persons who have never enjoyed legal residence in the Netherlands, since they are not registered in the Dutch Registry at all. This illustrates that the figure from the Netherlands tells us very little about the actual number of stateless persons in that country-it might be either underestimating or overestimating the true number.

It also transpires from UNHCR studies that Member States employ different techniques for collecting data, ${ }^{42}$ with them often being incomplete or inconsistent even within one state, ${ }^{43}$ and some Member States not collecting any statistical information on the number of stateless persons in their territories at all. ${ }^{44}$ It is beyond the scope of this paper to analyse how data is assembled in each Member State, but based on available studies, and taking account of the fact that adequate statelessness determination procedures are missing in a majority of EU Member States, it can be assumed that most figures circulating in the public domain are not representative, and that the scope of the statelessness phenomenon in the EU remains opaque.

\subsection{Demographic Composition of EU's Stateless Population}

Equally unfortunately, there is relatively little information available on profile of the stateless populations in the EU. With a view to provide some basic insight, however, and at risk of oversimplifying matters, it is possible to divide the stateless population into roughly three broad categories. ${ }^{45} \mathrm{~A}$ majority is formed by individuals who became stateless as a result of the dissolution of the Soviet Union and Yugoslavia. The largest group of stateless persons living in

41 According to the Centraal Bureau voor Statistiek (Dutch Central Statistics Office) there were 88,313 persons registered with 'nationality unknown' in 2012, as quoted in Adviescommissie Vreemdelingenzaken (ACVz), Geen land te bekennen (Dutch Advisory Committee on Migration Affairs, 'No country of one's own') Dec. 2013 (Den Haag, Acvz, 2013), p. 31. Statistics until 2010 are available on the website of the Centraal Bureau voor Statistiek at http://statline.cbs.nl/, under 'Bevolking: geslacht, leeftijd en nationaliteit. Cijfers van 1 januari 2010'.

42 Compare, for example, the UNHCR reports Mapping Statelessness in Belgium (Geneva, UNHCR, 2012), pp. 21-27; Mapping Statelessness in the Netherlands (Geneva, UNHCR, 2011), p. 17; and Mapping Statelessness in Finland (Geneva, UNHCR, 2014), pp. 14-22; and UNHCR, Global Trends 2013 (Geneva, UNHCR, 2014), data on stateless persons in Table 1 on pp. 40-44.

43 UNHCR, Mapping Statelessness in the U K (Geneva, UNHCR, 2011), pp. 28-54.

44 For example, Malta, see UNHCR, Mapping Statelessness in Malta (Geneva, UNHCR, 2014), pp. 46-47.

45 Cf. Manly, 2012, pp. 266-267. 
the EU are ethnic Russians in Latvia and Estonia who have often resided there since birth but who lack easy access to the nationality of these countries. Even though Latvia consistently defends the position that these former USSR citizens cannot be equated with stateless persons and excludes them from acquiring the status of stateless person in its national law, they meet the definition of a stateless person of Article 1 of the 1954 Convention. ${ }^{46}$ They are treated under specific regimes for 'non-citizens' (Latvia) or 'undefined citizens' (Estonia) and enjoy inter alia permanent residence, an aliens passport, diplomatic protection and equal treatment in the sphere of socioeconomic rights. Their special status bars them from political participation, however, and from practicing certain professions. ${ }^{47}$ Although their position is rightly identified as problematic for a range of reasons, their status compares favourably to many other categories of stateless persons in Europe. We do not expect that our proposal will have a substantial impact on their legal position, although they should be able to have their status as stateless person properly identified. This is particularly important if such a person establishes residence in another country. For example, if a Latvian non-citizen has been residing in another State and wishes to naturalise, his or her status as a stateless person may expedite access to that State's nationality, as is illustrated by the Irish case of Spila $v$ Minister for Justice, Equality and Law Reform..$^{48}$ Likewise, if a child is born to two 'noncitizens' in another State Party to the 1961 Convention, the recognition of statelessness of such a child would lead to access to the nationality of the state of birth. A significant development is that the Estonian parliament passed a law in January 2015 which opens up Estonian nationality to all stateless (i.e. 'undefined citizen') children born in Estonia. ${ }^{49}$ Legislative amendments of 2011 and 2013 in Latvia had also eased children's registration as Latvian citizens

46 According to Section 3(2) of the Latvian law on stateless persons: 'The status of a stateless person may not be acquired by a person who is the subject of Law On the Status of Those Former U.s.s.R. Citizens Who do not Have the Citizenship of Latvia or That of any Other State.' This was confirmed by Latvia Constitutional Court 7 March 2005, no. 2004-15-0106.

47 On the position of non-citizens of Latvia extensively: Kruma, K. 'Checks and balances in Latvian nationality policies: National agendas and international frameworks', in R. Bauböck, B. Perchinig, W. Sievers (eds) Citizenship Policies in the New Europe (Amsterdam, Amsterdam University Press, 2009), pp. 63-88.

48 Irish High Court, 31 July 2012, Spila v Minister for Justice, Equality and Law Reform [2012] IEHC 336 .

49 UNHCR Press release 21 January 2015, 'Estonia makes milestone changes to its citizenship act'. 
upon birth. ${ }^{50}$ This has the potential to halt the perpetuation of statelessness in these countries.

Roma have also been disproportionately affected by state succession, because they often lack proper registration and documentation necessary to obtain proof of nationality. Statelessness often amplifies the social exclusion of Roma, as the lack of documentation hinders their access to education, health care, social assistance and the right to vote. ${ }^{51}$ Large numbers of stateless persons are reported to live in Central and Eastern Europe, and in particular the Western Balkans, but statelessness is also documented in Western European Roma communities who may either have moved there as refugees or migrants from mostly Eastern Europe, or have longstanding intergenerational ties to the countries concerned. ${ }^{52}$

A second category is formed by individuals born in Europe who became stateless due to conflicting nationality laws or gaps in nationality laws, such as provisions not permitting women to pass on their nationality to their children, lack of provisions on the nationality status of foundlings, or provisions limiting the ius soli acquisition of nationality for otherwise stateless children. ${ }^{53}$ Fortunately, most countries in Europe seriously try to avoid cases of statelessness from arising and much progress has been made in the last few decades in erasing gender-based discrimination in nationality laws, thereby reducing the situations in which children born abroad, out of wedlock and/or of mixed nationality parentage become stateless. ${ }^{54}$

A third category is formed by migrants and their offspring who either were stateless upon arrival or became stateless thereafter. Common profiles of stateless persons are, for example, Kuwaiti Bidoon and Palestinians in the United Kingdom, ${ }^{55}$ Palestinians and persons originating from Kosovo and Syria in

5o See, extensively: Djackova, S., 'Statelessness among children in Latvia: current situation, challenges and possible solutions', European Network on Statelessness blog, September 2014, available at http://www.statelessness.eu/blog/statelessness-amongchildren-latvia-current-situation-challenges-and-possible-solutions.

51 Council of Europe, Human Rights of Roma and Travellers in Europe, (Strasbourg, Council of Europe Publications, 2012), p. 184.

$5^{2}$ Ibid., p. 189. See for, example, a study on statelessness within Roma communities in Italy: CIR, In the Sun, Survey on the phenomenon of statelessness among Roma communities living in Italy, February 2013 (Rome, CIR, 2013), available at: http://www.cironlus.org/ images/pdf/'In\%2othe\%2osun'_CIR_last\%2oreview_final.pdf.

53 Vonk, O., M. Vink, G.-R. de Groot, Protection against statelessness: trends and regulations in Europe, Eu I Working Paper (Florence, European University Institute, 2013), pp. 10-11.

54 Ibid., p. 105.

55 UNHCR, Mapping Statelessness in the United Kingdom (Geneva, UNHCR, 2011), p. 17. 
Finland, ${ }^{56}$ Moluccans and other persons originating from Indonesia in The Netherlands, ${ }^{57}$ and persons who were born in the former Soviet Union and former Yugoslavia in Belgium. ${ }^{58}$

Obviously, the different categories of stateless persons in Europe reflect the many conceivable causes of statelessness, ranging from conflicting or discriminatory nationality laws, to loss of nationality in the context of state succession, to withdrawal due to fraudulent naturalisation and so on. Stateless persons may have been born in the EU or entered it later in life, they may enjoy legal residence or be undocumented, and they may be refugees, rejected asylum seekers, or persons who entered the country without ever bringing an asylum claim. Protection needs vary from group to group and from person to person. Indeed, many stateless persons in Europe already enjoy a high level of protection. Statelessness does not have to result in a humanitarian problem, or grave violations of basic human rights. If adequate identification and protection mechanisms are in place, stateless persons can have access to basic rights, or even enjoy all the benefits available to nationals. ${ }^{59}$

\subsection{Protection Failures in E U Member States}

A comprehensive protection regime for stateless persons requires, first of all, a mechanism for the identification of the status of stateless persons, and secondly rules and procedures for obtaining a secure residence status in a particular country. All stateless persons need access to a mechanism to establish the legal fact of their statelessness, regardless of their background or legal situation. They should also be able to enjoy the minimum protection of the 1954 Convention, which can usually best be achieved by granting stateless persons the right of legal residence. However, unlike access to status determination, access to legal residence is not always necessary for ensuring appropriate protection. Sometimes stateless individuals are already residing legally in their host state on other grounds, such as asylum, family reunification, or work. In

56 UNHCR, Mapping Statelessness in Finland (Geneva, UNHCR, 2014), pp. 17-18.

57 UNHCR, Mapping Statelessness in the Netherlands (Geneva, UNHCR, 2011), p. 24.

$5^{8}$ UNHCR, Mapping Statelessness in Belgium (Geneva, UNHCR, 2012), p. 32.

59 An example of the latter is a small stateless population in the Netherlands originating from the Moluccan islands; see more in Adviescommissie Vreemdelingenzaken (ACVz), Geen land te bekennen (Dutch Advisory Committee on Migration Affairs, 'No country of one's own'), Dec. 2013 (Den Haag, ACvz, 2013), pp. 31-32.The non-citizens of Latvia and Estonia are examples of stateless populations with access to decent standard of living in their countries of residence (even though their lack of citizenship is highly controversial from the political point of view, and they lack a number of political rights). 
other cases there might be more appropriate solutions for residence available abroad. ${ }^{60}$

At present, the Member States of the European Union are largely failing to provide comprehensive protection to stateless persons. First, only seven EU Member States have dedicated statelessness determination procedures, namely France, Italy, Spain, Hungary, the United Kingdom, Latvia and Slovakia. ${ }^{61}$ In other Member States, formal determinations of statelessness are either impossible or happen sporadically and ineffectively. ${ }^{62}$ Moreover, existing statelessness determination procedures are critiqued for lack of procedural guarantees, administrative and practical impediments in access to the procedure, poor coordination with asylum procedures, a lack of clarity regarding rules on evidence and interpretations of the definition of stateless person which deviate from UNHCR guidelines. ${ }^{63}$ This endangers the proper implementation of the 1954 Convention, and may also lead to violations of the 1961 Convention. Even though UNHCR has emphasised that the obligation to establish an adequate status determination procedure is implied in the Conventions, and has issued

6o UnHCr, Handbook on the Protection of Stateless Persons (Geneva, UnHCr, 2014), pp. $54-55$.

61 See European Network on Statelessness (ENS), Statelessness Determination and the Protection Status of Stateless Persons: A summary guide of good practices and factors to consider when designing national determination and protection mechanisms (London, ENS, 2013), p. 9. In addition, Belgium does not have a dedicated determination procedure, but the establishment of the statelessness status can take place in courts, see UNHCR, Mapping Statelessness in Belgium (Geneva, UNHCR, 2012), pp. 47-63.

62 See Batchelor, C., 'The 1954 Convention Relating to the Status of Stateless Persons: Implementation Within the European Union Member States and Recommendations for Harmonization', 22(2) Refuge (2005) 31-58; Swider, K., Statelessness Determination in the Netherlands, Research Paper No. 2014-04 (Amsterdam, Centre for European Law and Governance, 2014), accessible on SSRN at http://ssrn.com/abstract=2434573; UNCHR, Mapping Statelessness in the Netherlands (Geneva, UNHCR, 2011), pp. 33; UNHCR, Mapping Statelessness in Malta (Geneva, UNHCR, 2014), pp. 46-56; UNHCR, Mapping Statelessness in Belgium (Geneva, UNHCR, 2012), p. 17.

63 See in general Bittoni, G., 'Statelessness in the European Union', 19 Tilburg Law Review: Global Law Special Issue - Statelessness (2014) 52-63. Also see Groot, G.R. de, K. Swider, O. Vonk, Practices and Approaches in EU Member States to Prevent and End Statelessness, Study for the LIBE Committee, Nov. 2015, (Brussels, European Parliament, 2015), pp. 4851. On the French determination procedure specifically, see Chassin, C.-A., 'Panorama français du droit de l'apatridie', 2 Revue française de droit administratif (2003) 324-330; Likibi, R., Le droit de l'apatridie: pratiques et controverses (Paris, Publibook, 2013), pp. 257-303. 
detailed guidelines on the design and standards of such a procedure, Member State practices deviate considerably from the standards set by UNHCR. This in itself testifies to the need for more authoritative interpretative guidance and supervision at a supranational level. ${ }^{64}$

Further, the absence in many Member States of a route by which stateless persons can regularise their status leaves some stateless persons at risk of permanent marginalization. Although the two UN Conventions do not specify when and how a residence permit needs to be issued to a stateless person, legal residence appears a crucial condition in a majority of - if not all-EU Member States for being able to access fully the protection regime of the 1954 Convention. ${ }^{65}$ In the context of the 1951 Refugee Convention, which also does not foresee in an explicit entitlement to legal residence, it has long been recognised by virtually all State Parties that granting residence, initially temporary, is in many cases the only appropriate solution for refugees-simply because they cannot return to their country of origin. Likewise, for stateless persons who are not admissible into another State, a statelessness-specific residence ground may be the only means by which they can secure a place to build a life. This is, however, reflected in the immigration regimes of only a handful of Eu Member States. ${ }^{66}$ In other Member States, stateless persons may be able to establish residence on other (humanitarian) grounds, but those do not guarantee that every stateless person enjoys adequate protection. ${ }^{67}$ In Germany, for example, stateless persons whose deportation proves impossible can receive a toleration certificate (Duldung) or in some cases even a residence permit (Aufenthaltserlaubnis), but neither of these statuses guarantees

64 Mandal, R., Procedures for Determining Whether a Person is Stateless, Discussion paper No. 3 for the UNHCR Handbook on the Determination of Statelessness, November (Geneva, UNHCR, 2010), p. 6.

65 See also UNHCR, Handbook on Protection of Stateless Persons (Geneva, UNHCR, 2014), para $147-150$.

66 These are all the Member States with a statelessness determination procedure: France, Italy, Spain, Hungary, Slovakia, United Kingdom and Latvia. See the European Network on Statelessness (ENS), Statelessness Determination and the Protection Status of Stateless Persons: A summary guide of good practices and factors to consider when designing national determination and protection mechanisms (London, ENS, 2013), p. 36. In addition, in Belgium a right of residence can be granted to those who have been identified as stateless in court, see UNHCR, Mapping Statelessness in Belgium (Geneva, UNHCR, 2012).

67 See Batchelor, C., 'The 1954 Convention Relating to the Status of Stateless Persons: Implementation Within the European Union Member States and Recommendations for Harmonization', 22(2) Refuge (2005) 44. See also UnHCR, Mapping Statelessness in the Netherlands (Geneva, UNHCR, 2011), pp. 44-45. 
sufficient protection and access to rights in line with the 1954 Convention. ${ }^{68}$ In the Netherlands, stateless persons who can substantiate their inability to leave the Netherlands due no fault of their own, can in theory obtain the socalled 'no-fault' residence permit (buitenschuld-vergunning). ${ }^{69}$ In practice, however, 'no-fault' residence permits are only sporadically issued, and statelessness of the applicants is not taken into account when deciding on the application. ${ }^{70}$ In Poland, permission for tolerated stay (zgoda na pobyt tolerowany) can be granted to a stateless person against whom a deportation order cannot be executed ${ }^{71}$ but the requirement of a prior attempted deportation, which needs to be initiated by state authorities, significantly inhibits access to this procedure.

The last decade has brought a number of positive developments in the protection regimes for stateless persons in the EU. By now, all but four EU Member States have acceded to or ratified the 1954 Convention, ${ }^{72}$ and a majority has ratified or acceded to the 1961 Convention. ${ }^{73}$ There is a pending commitment from 2012 by the EU Member States who have not yet done so to ratify the 1954 Convention and 'to consider' ratifying the 1961 Convention. ${ }^{74}$ No less significant is that a number of EU Member States have recently established or improved mechanisms for the identification and protection of stateless persons, or have committed to taking steps in that direction in the near future. In the United Kingdom, a new statelessness determination procedure took effect on 6 April 2013, which allows stateless persons to be formally recognised as such and to legalize their presence in the United Kingdom, if they are not admissible to another country. ${ }^{75}$ In 2011, Belgium announced that it would make the Commissariat général aux réfugiés et aux apatrides, the body responsible for refugee status determination, competent to recognise the status of

68 Bianchini, K., 'On the Protection of Stateless Persons in Germany', 19 Tilburg Law Review (2014) 42-46.

69 Vreemdelingenbesluit (Aliens Decree) 2000, art. $3 \cdot 4$ (1W).

70 JaghaI, S., C. Vlieks, 'Buitenschuldbeleid schiet tekort in bescherming staatlozen', 05/06 Asiel- \& Migrantenrecht (2013) 287-292.

71 Art. 352(2) of the Polish Law on Foreigners of 8 October 2013 (entry into force 1 May 2014). See also Gyulai, G., Forgotten without Reason. Protection of Non-refugee Stateless Persons in Central Europe (Budapest, Hungarian Helsinki Committee, 2007), p. 20, 26.

72 The exceptions are Cyprus, Estonia, Poland and Malta.

$73 \quad 18 \mathrm{EU}$ Member States are parties to the 1961 Convention as of 27 July 2016.

74 Note Verbale from the European Union to the United Nations of 19 September 2012, section A, para 4, available at www.unrol.org/files/Pledges\%2oby\%2othe\%2oEuropean\%20 Union.pdf.

75 United Kingdom Immigration Rules, para 403. 
stateless persons, which should lead to a grant of temporary residence. ${ }^{76}$ This decision could not be implemented, however, because Art. 144 of the Belgian Constitution bestows the competence over the settlement of disputes relating to the civil status of persons on courts. Therefore, in the Government Agreement of October 2014, a renewed pledge is included to set up an 'adequate procedure' for recognising the status of stateless persons, which should lead to a grant of temporary residence, to be decided on by civil courts with an advisory role of the Commissariat général aux réfugiés et aux apatrides. ${ }^{77}$ In January 2012, the Belgian Constitutional Court had decided that the Belgian legislator should treat recognised stateless persons who have involuntarily lost their nationality and who cannot acquire residence in another country in a similar manner as refugees and thus grant them residence. ${ }^{78}$ Upon advice of the Dutch Advisory Committee for Aliens Affairs, the Dutch government announced in September 2014 that it would introduce a statelessness determination procedure, although it did not take up the suggestion to make statelessness as such a ground for residence. ${ }^{79}$ Worth mentioning, further, is that in February 2015, the Constitutional Court in Hungary declared unconstitutional that only lawfully staying persons could initiate a statelessness determination procedure, as this modifies and unduly narrows the definition of stateless person of Article 1 of the 1954 Convention. ${ }^{80}$ There is, in sum, a clear European trend towards establishing properly functioning statelessness protection regimes.

It does not seem that ratification of or accession to the 1954 Convention or the establishment of statelessness determination procedures leads to a significant increase in arrivals of stateless persons or persons applying for stateless status. France, which is one of the few countries with a relatively well-functioning statelessness determination procedure and which produces reliable data, registered between 182 and 272 applicants for stateless status annually in the years $2010-2014$, with a recognition rate between $15-34 \%{ }^{81}$ The stateless-

\footnotetext{
$76 \quad$ Federaal Regeerakkoord 1 December 2011, para 2.7.8.

77 Federaal Regeerakkoord 9 October 2014, p. 154.

78 Belgisch Grondwettelijk Hof 11 January 2012, no. 1/2012. Also see Hof van Beroep Brussel 17 September 2014, no. 2014/7124.

79 Letter from the Dutch Ministry of 10 September 2014 'Eerste reactie van het kabinet op het advies van de ACVZ inzake staatloosheid'. See also Proposed Law 'Determination Procedure for Statelessness' (Wetsvoorstel Rijkswet vaststelingsprocedure staatloosheid) of 28 September 2016.

8o Judgment of the Constitutional Court of Hungary No. III/01664/2014, of 23 February 2015.

81 European Migration Network Ad-Hoc Query on recognition of stateless persons, 4 May 2015 .
} 
ness determination procedure that entered into effect in the United Kingdom in April 2013 resulted in 226 applications in 2013 and 557 applications in 2014, with only 2 and 14 statuses granted in those years, respectively. ${ }^{82}$ These (very) low numbers take away fears that statelessness determination procedures would create a pull-factor.

\section{The Rationales for EU Action on Statelessness}

In our view, there are two persuasive sets of arguments for promoting and consolidating the aforementioned trend by way of EU legislative action. The first one centres on human rights and relates to the protection gaps and implementation failures of the 1954 Convention as identified in sections 2 and 3 : the lack of statelessness determination procedures in many EU Member States, divergent interpretation and application of the definition of 'stateless person', the silence of the UN Conventions on the issue of legal residence, the outdated catalogue of rights of the 1954 Convention and the lack of effective supervision and monitoring.

Union law can address all these issues. First, the EU is competent to set the conditions of residence of third-country nationals, including stateless persons, and to define the rights of third-country nationals and stateless persons residing legally in a Member State. ${ }^{83}$ Second, this competence includes the setting of procedural guarantees for making those rights effective, which can take the form of a statelessness determination procedure. Third, an EU legislative instrument can provide common interpretations of elements of the definition of a stateless person, much similar as the EU Qualification Directive does in respect of the refugee definition of Article $1 \mathrm{~A}(2)$ of the Refugee Convention. ${ }^{84}$ Fourth, an EU legislative instrument could lay down a rights regime for stateless persons which integrates the rights of the 1954 Convention and those contained in other human rights instruments, in a similar fashion as the refugee rights regime laid down in Chapter VII of the EU Qualification Directive. And fifth, regulating the legal position of stateless persons in Union law ensures more effective compliance by virtue of Eu law having direct effect in the domestic legal orders of the Member States and EU institutional enforcement mechanisms.

\footnotetext{
$82 \quad$ Ibid.

83 See further sections 5.1 and 5.2 below.

84 Art. 9-12 Directive 2011/95/EU.
} 
Our second set of arguments is comprised of EU rationales for harmonization. First, approximating rights of entry and residence of third-country nationals and stateless persons, as well as the standard of treatment to be accorded to them, is an objective of the Union and laid down in Article 79 TFEU. The rationale of this objective is that in a Union area without internal frontiers, disparities in the treatment of third-country nationals (and stateless persons) may result in undesirable 'push' and 'pull' effects which cannot be effectively controlled due to the absence of internal border controls.

This rationale includes taking measures to preclude the so-called 'race to the bottom' effect. The experience with establishing the Common European Asylum System shows that a protection regime for vulnerable groups in the EU needs to be coordinated on the EU level to avoid dynamics by which stateless persons will choose to seek protection in the Member State which they consider most attractive. To counter that effect, Member States may not only feel reluctant to increase their level of protection but may indeed be tempted to decrease their relative attractiveness compared to other Member States, potentially prompting a race to the bottom and resulting in an overall lowering of the level of protection across the EU. There is no evidence whether any significant numbers of stateless persons actually engage in such a 'forumshopping' behaviour, and whether that behaviour influences the policies of individual Member States. However, in the context of open borders, it is the EU's responsibility to ensure that such considerations do not play a role in domestic decision-making. Member States which strive to comply with their international obligations on statelessness should not be hindered by fears of attracting disproportionate numbers of stateless persons from other Member States. Similar to the reasons advanced for establishing a common European asylum policy, therefore, the rationale for $\mathrm{EU}$ action on statelessness would be to create a level legal playing field, which prevents forum-shopping and ensures in all Member States a minimum level of protection in accordance with international obligations. ${ }^{85}$

Further, the need for well-functioning procedures through which statelessness can be determined is already implied in existing EU law. Since Eu law treats stateless persons as third-country nationals (Art. 67(2) TFEU), such persons fall within the personal scope of all EU legislative instruments on migration, such as the EU asylum directives, the Family Reunification Directive (2003/86/ EC), and the Return Directive (2008/115/EC). Insofar as national procedures

85 Cf. the rationales for establishing a Common European Asylum System as formulated in the Tampere Programme, Conclusion of the European Council of 15/16 October 1999. 
for determining statelessness affect the rights conferred and protected by the legal order of the Union, such procedures lie within the scope of Union law and must take due regard of the principles of Union law. ${ }^{86}$ Although it will normally not matter for the application of those directives whether a person is stateless or a third-country national, rendering it unnecessary to make a formal distinction in individual cases, some provisions in these Directives do have different legal effects for persons with and persons without a nationality. For example, Article 36 of the Asylum Procedures Directive (2013/32/EU), laying down the 'safe country of origin'-concept, sets forth that for persons with a nationality, only the country of nationality can be a safe country of origin. The country of origin of stateless persons, however, is defined as any country where they have been formerly habitually resident.

Not only the distinction between stateless persons and third-country nationals is relevant under existing Union law. Even more consequential would be a failure to properly identify whether someone is stateless or in fact a Union citizen. If France, for example, wishes to forcibly evict Roma from illegally set up camps and expel them from its territory, it makes quite a difference for their position under EU law whether they are treated as stateless or as a national of another Member State and thus an EU citizen. ${ }^{87} \mathrm{~A}$ lack of clarity in such cases bears with it the risk that persons are treated under the wrong legal regime. It could well be argued that in those cases, the principle of giving useful effect to EU law already obliges Member States to have in place fair procedures for determining whether a person is stateless.

Finally, increasing the level of protection of stateless persons and ensuring their participation in socioeconomic life squares fully with the foundational values of the Union, namely respect for human dignity and other human rights, combatting social exclusion and discrimination, and promoting integration policies which foster social cohesion and economic dynamism. ${ }^{88}$

86 See, mutatis mutandis, Case C-135/08 (Rottmann), para 42, 48.

87 For a comparable case in The Netherlands, see District Court The Hague 5 August 2009, ECLI:NL:RBSGR:2009:BJ6433, concerning a person with an ineffective nationality of former Czechoslovakia, whose residence right in the Netherlands depended on whether he was to be recognized as stateless or as a Slovak national.

88 Art. 2 and 3 TEU. Also see Conclusions of the European Council of 26/27 June 2014, para 1.6. 
Yet, the proposition that the Union is well placed to legally act on statelessness must overcome concerns relating to the division of competences between the Union and the Member States. Existing literature which touches on the EU's potential to act on statelessness points to two obstacles in this respect. ${ }^{89}$ The first is that any legislative action is likely to intervene in the sovereign prerogatives of the Member States in the area of nationality laws. Second, it has been submitted that there is no legal basis in EU treaties for regulating the legal position of stateless persons as such. We will address these concerns in turn and will also say a few words about why our proposal complies with the Union's subsidiarity principle.

\subsection{Member States' Prerogatives in Nationality Matters}

The Member States have been protective of their sovereignty in nationality matters ever since the concept of Union citizenship started to take ground. The crucial disclaimer to Union citizenship, laid down in Art. 20(1) TFEU, is that '[c]itizenship of the Union shall be additional to and not replace national citizenship'. The caveat has been in force since the 1997 Treaty of Amsterdam, albeit in slightly different wordings. ${ }^{90}$ When the Treaty of Maastricht first introduced the concept of European citizenship into the Treaties in 1992, Member States were adamant to claim ownership over nationality matters in a number of documents. ${ }^{91}$ The Edinburgh Decision, adopted by the European Council with a view to clarifying the Treaty of Maastricht, affirms that ' $\mathrm{t}$ ] he question whether an individual possesses the nationality of a Member State will be settled solely

89 See Gyulai, G., 'Statelessness in the EU Framework for International protection', 14 European Journal of Migration and Law (2012) 284; Molnar, T., 'Stateless Persons under International Law and EU Law: a Comparative Analysis Concerning their Legal Status, with Particular Attention to the Added Value of the EU Legal Order', $5_{1}$ Acta Juridica Hungarica (2010) 304, and Molnar, T., 'Moving Statelessness Forward on the International Agenda', 19 Tilburg Law Review (2014) 198.

90 According to Article 8(1) of the Treaty Establishing the European Community, as amended by the Treaty of Amsterdam of 1997, 'Citizenship of the Union shall complement and not replace national citizenship'. See for commentary on the change of wording Nic Shuibhne, N., 'EU Citizenship After Lisbon', in D. Ashiagbor, N. Countouris, I. Lianos (eds), The European Union After the Treaty of Lisbon (Cambridge, Cambridge University Press, 2012), p. 139 .

91 Edinburgh Decision of 1992, OJ 1992, C 348, p. 1; Declaration No. 2 on Nationality of a Member State, annexed to the Treaty on European Union, (OJ 1992 C 191, p. 98). 
by reference to the national law of the Member State concerned.92 The same message features in Declaration No. 2 on nationality of a Member State, annexed to the Treaty on European Union in 1992. ${ }^{93}$ It is worth noting that this declaration was dropped during the latest amendment of the European Union Treaties by the Treaty of Lisbon in 2009. The disappearance of the Declaration from the Treaty texts has largely gone unnoticed, and the Declaration is still occasionally referred to in post-Lisbon documentation. ${ }^{94}$

It is clear that EU measures aimed at avoidance of statelessness will have an adverse impact on the prerogative of Member States to regulate their nationality laws. Such EU legislation most likely would involve a requirement on Member States to grant nationality to persons in the situations specified in the 1961 Convention. By contrast, legislation on the identification and protection of stateless persons - the subject of our proposal—does not in itself affect sovereignty in the field of nationality. It would only facilitate the recognition of the status of stateless person as defined in international law and set their standard of treatment as well as the conditions for granting them lawful residence.

Admittedly, a determination of statelessness or the granting of legal residence to a stateless person is likely to have the effect that the person would qualify for acquisition of nationality under Member States' nationality laws, as may be the case with stateless children born in a Member State or after prolonged lawful residence in the Member State. However, this need not constitute a bar for adopting such rules, as it is generally accepted that nationality laws of the Member States may be influenced, in a variety of ways, by Union law. Even though the Treaty does not endow the EU with the competence to regulate the acquisition and loss of nationalities of Member States, the influence of EU law on nationality matters is inevitable and frequent. At the current state of development of EU law, it is apparent that the EU has a strong impact on Member States' nationality laws and policies through, for example, the formation of the rights of $\mathrm{EU}$ citizens, the legislation on asylum and immigration, and the case law of the CJEU.

First, secondary EU legislation on free movement of EU citizens, immigration of third-country nationals and asylum has an impact on access to nationalities of the Member States. For example, the requirement of legal residence for a certain number of years is usually central to accessing nationality through

92 Edinburgh Decision of 1992, OJ 1992, C 348, p. 1.

93 Declaration No. 2 on Nationality of a Member State, annexed to the Treaty on European Union (OJ 1992 C 191, p. 98).

94 See, for example, Opinion of the Advocate General Szpunar of 20 May 2014 in Case C-202/13 (McCarthy), para 45, footnote 24 . 
naturalization. Individuals who derive their right to reside legally in a Member State through EU legislation may qualify for naturalization because of such legislation. ${ }^{95}$ The cases of Zhu and Chen and Ruiz Zambrano, which prompted amendments of respectively Irish and Belgian nationality laws, are prime examples of how EU free movement rights affect a Member State's policy on the acquisition of nationality iure soli. ${ }^{96}$ Moreover, existing EU directives, such as the Qualification Directive and Long Term Resident Directive, have a similar effect, as most nationality laws allow refugees or permanent residents to obtain nationality after a certain period of legal residence. Despite this effect, the requirements for naturalizing refugees or long-term residents remain within the competence of Member States. A statelessness identification and protection directive would be of similar scope.

Second, an established line of case law of the CJEU requires the Member States to have 'due regard' to EU law when regulating access to their nationalities. ${ }^{97}$ The exact scope of the term 'due regard' is being gradually defined by the CJEU in its case law on EU citizenship. The Rottmann judgment ${ }^{98}$ made clear that particularly when statelessness is at stake, the CJEU is prepared to hold Member States' nationality practices to high international standards. In this case, the CJEU recognised that Germany was in principle free to decide who acquires and who loses German nationality, but those decisions need to have due regard to EU law, as withdrawal of German nationality in the case of Rottmann also meant that EU citizenship was lost. The Court assessed, therefore, whether the decision to withdraw Rottmann's nationality was in line with the 1961 Convention and the European Convention on Nationality,

95 See more in Swider, K., Pre-Accession Changes to Residence-based Naturalisation Requirements in Ten New EU Member States, EUI Working Paper Series (Florence, European University Institute, 2010), pp. 3-4.

96 ECJ, Case C-200/o2 Zhu and Chen of 19 October 2004; ECJ, Case C-34/og Ruiz Zambrano of 8 March 2011; Irish Nationality and Citizenship Act of 2004, No. 38, Amending Irish Nationality and Citizenship Act of 1956, adopted on the 15th December 2004, entered into force on the 1st January 2005. See also Act on the Twenty-Seventh Amendment of the Irish Constitution of 24th June 2004, based on the referendum on the 11th of June 2004; Rostek, K. \& G. Davies, 'The Impact of Union Citizenship on national citizenship', 10(5) European Integration Online Papers (2006), part 3.3. See also the amendment of Art. 10 of the Belgian Law on Nationality (Wetboek van de Belgische nationaliteit 1984) of 28 December 2006 (by the Law Nr. 2006-12-27/32, art. 380, 009).

97 See ECJ C-369/9o, Micheletti, 7 July 1992, and other judgments that followed on nationality matters, such as C-192/99 (Kaur) of 20 February 2001; C-200/02 (Zhu and Chen) of 19 October 2004.

98 Judgment of the ECJ C-135/o8 (Rottmann) of 2 March 2010. 
and whether it was consistent with the principle of proportionality. Rottmann has not remained without criticism, including from the UK Supreme Court in Pham; the critique centring especially on the applicability of Union law to withdrawals of nationality where no cross-border element is at issue. ${ }^{99}$ Our proposal for EU action does not, however, deal with national decisions to grant or withdraw nationality, but is about solidifying the protected status attached to the legal fact of statelessness.

\subsection{Treaty Basis}

Unlike its predecessors, the Lisbon Treaty specifically addresses the legal position of stateless persons. According to Article 67(2) TFEU, such persons are, for the purposes of Title V TFEU (The Area of Freedom, Security and Justice), to be equated with third-country nationals. This makes the Union competent to set the conditions for entry and residence of stateless persons in a similar fashion as it does for third-country nationals. Indeed, the definitional provisions contained in secondary legislation adopted on the basis of Article 78 TFEU (the common asylum policy) explicate that it applies equally to stateless persons and third-country nationals. ${ }^{100}$ This is also true for legislation adopted on the basis of Art. 79 TFEU (the common immigration policy), such as the Family Reunification Directive, the Long-term Resident Directive, the Returns Directive, the Students Directive and the Blue Card Directive: by negatively defining third-country nationals as 'any person who is not a citizen of the Union', they include stateless persons in their scope. ${ }^{101}$ Although the heading of Chapter 2 of Title V TFEU suggests that it applies only to migrants, it should be noted that Articles 78 and 79 pertain to all third-country nationals and stateless persons, wherever they are born and whether or not they have crossed any borders. Therefore, stateless persons born and residing in a single EU Member State may fall within the ambit of secondary legislation ensuing from Articles 78 and 79 TFEU.

The EU legislator has, accordingly, already regulated the position of stateless persons extensively on the basis of Articles 78 and $79 \mathrm{TEU}$ and stateless persons may well base rights of residence and guarantees on their treatment on existing EU legislation. However, not all stateless persons necessarily fall in the scope of any of the relevant directives. Moreover, none of the directives

99 Pham $v$ Secretary of State for the Home Department [2015] UKSC 19, para 55 (Lord Carnwath) and 69-71 (Lord Mance).

100 See eg Art. 1 Directive 2011/95/EU (Qualification Directive).

101 Art. 2(a) Directive 2003/86/EC, Art. 2(a) Directive 2003/109/EC, Art. 3(1) Directive 2008/115/EC, Art. 2(a) Directive 2004/114/EC, Art. 2(a) Directive 2009/50/EC. 
adopted on the basis of Articles 78 and 79 TFEU contain protection regimes that are specifically tailored to stateless persons.

In view of the close historical and legal ties between the protection regimes for refugees and stateless persons, it could be argued that, in the absence of an explicit legal basis in the Treaties, the Union's common policy on stateless persons may be built on Art. 78 TFEU. However, and unless they fear persecution in their former country of habitual residence, stateless persons do not require the same type of protection as asylum seekers and refugees, as the key protections in the asylum context, namely against persecution and refoulement, are not at stake. ${ }^{102}$ On the national level, some EU Member States do group statelessness together with asylum-related procedures, but others do not. In France, for example, stateless persons and asylum seekers are assisted by the same state authority, the French Office for Protection of Refugees and Stateless persons. ${ }^{103}$ In the Netherlands, on the other hand, the residence status originally intended for stateless persons (buiten schuld-vergunning or 'no fault permit') is grouped together with 'regular' (non-asylum) residence statuses. ${ }^{104}$ In all likelihood, the objectives formulated in Art. 78 TFEU, referring to international protection, non-refoulement and the 1951 Refugee Convention and subdividing this into rules on 'asylum', 'subsidiary protection' and 'temporary protection' - all terms with specific meanings in asylum law-are too narrow for adopting an integrated policy on statelessness. ${ }^{105}$

Alternatively, the flexibility clause (Art. $35^{2} \mathrm{TFEU}$ ) in conjunction with Art. 67(2) TFEU has been suggested as possible legal basis. ${ }^{106}$ As described above, Article 67(2) TFEU formulates the aim of creating a common policy on asylum, immigration and external border control which is fair towards thirdcountry nationals and to that purpose equates stateless persons with thirdcountry nationals. The flexibility clause allows the Union's competences to be adjusted to the objectives laid down by the Treaty when the latter has not provided the powers of action necessary to attain them. It could be argued that by mentioning stateless persons and equating their status to those of thirdcountry nationals, the Treaty brings statelessness within the scope of its

102 See UnHCR, Guidelines on Statelessness No. 2 (Geneva, UN HCR, 2012), para 26-30.

103 French Office for Protection of Refugees and Stateless persons (OFPRA), see more at www.ofpra.gouv.fr.

104 Vreemdelingenbesluit (Aliens Decree) 2000, art. 3.4 (1w).

105 Cf. Case C-130/10, Parliament v Council, para 42-45; CJEU 11 June 2014, Case C-377/12, Commission v Council, para 34.

106 See in Molnar, T., 'Moving Statelessness Forward on the International Agenda', 19 Tilburg Law Review (2014) 198, footnote 21. 
objectives, and if no Treaty provision specifically creates a legislative competence to attain that objective, Article $35^{2}$ TFEU can be used.

We feel, however, that it is unnecessary (and therefore legally objectionable) to rely on Art. $35^{2} \mathrm{TFEU}$, because Art. $79 \mathrm{TFEU}$ already provides the necessary powers. For the purposes of developing a common immigration policy, paragraph 2(a) contains the legal basis for defining the conditions of entry and residence of third-country nationals. Paragraph $2(b)$ is the legal basis for defining the rights of persons who reside legally as third-country national in a Member State. It follows from Art. 67(2) that both paragraphs apply to stateless persons as well. There is nothing in the text of Art. 79(2)(a) which precludes defining the circumstances under which statelessness per se is a ground for residence. The fact of being stateless may, just as the fact of being a third-country national student having been accepted at a European university, the fact of being a third-country national with a work contract with a European employer and meeting a certain salary threshold, or the fact of being a third-country national with a hosting agreement with a European research institute-all categories which are not specifically mentioned in Art. 79 TFEU but do benefit from EU legislative action-be formulated as a ground for residence in Union law. Art. 79 T FEU does not in any way exclude certain motives for granting residence from its scope. On the contrary, its very aim is to harmonize these motives.

Article 79 TFEU must also be considered to make the EU competent to establish common standards on statelessness determination procedures. If protection takes the form of a residence status on the grounds of statelessness, the mechanism for establishing statelessness is obviously essential for access to this status and the competence to set rules in that respect is therefore inherent in Art. 79(2)(a). Other directives adopted on the basis of Article 79 TFEU, such as the Students Directive (2004/114/EC), the Family Reunification Directive (2003/86/EC), and the Long-Term Residence Directive (2003/109/EC) also contain extensive rules on the procedural framework for determining whether the conditions for residence are met.

\subsection{Subsidiarity}

The subsidiarity principle sets out that the EU should only act if the objectives of the proposed action cannot be sufficiently met by the Member States and that Union action shall not exceed what is necessary to achieve the objectives of the Treaty. ${ }^{107}$ We have already formulated a number of Union rationales for harmonizing Member States' legislation on statelessness in section 4 above. The most forceful subsidiarity argument for EU legislative action is that within

107 Art. 5(3)-(4) TEU. 
an area without border controls, decisions on the residence of third-country nationals, including stateless persons, taken by one Member State may have effects on other Member States. As explained above, Member States' practices and legislation display considerable differences in the treatment of stateless persons. This may have undesirable cross-border effects which can be countered by a common framework for the identification and protection of stateless persons.

Although one may argue that addressing protection gaps in the 1954 Convention falls primarily to the parties to the 1954 Convention rather than the $\mathrm{EU}$, it is to be observed that non-EU state parties do not necessarily have an interest in harmonizing their implementation of the 1954 Convention to the same extent as EU state parties-precisely because they do not partake in the Union area of free movement.

The legislative act we propose should set out common goals in the field of identifying stateless persons as well as their standard of treatment that all EU countries must achieve. It would be up to the individual Member States to ensure that their national laws meet those goals. Although recent experiences with secondary migration of asylum seekers prompted the European Commission to issue proposals to transform the asylum directives into regulations, ${ }^{108}$ in respect of statelessness a directive would probably be a suitable legal act. Below, we explain what the key legal elements of such a directive would be. It is neither useful nor necessary at this stage to go into each and every legislative detail. Yet we do outline the issues that need to be addressed at the very least and how, in our view, the most critical issues should be resolved.

\subsection{Statelessness Determination Procedure}

An obligation on all Member States to have in place an accessible and fair procedure for the determination of statelessness would greatly improve the legal position of stateless persons in many Member States. As noted above, a determination of statelessness is a logical prerequisite for invoking the rights set out in the 1954 Convention.

Just as in the asylum context, a determination of the status of stateless person is necessary for a person to be granted protection, including legal

$108 \operatorname{com}(2016) 466$ final; $\operatorname{com}(2016) 467$ final. 
residence. ${ }^{109}$ Unlike in the refugee context, however, a determination of statelessness is important for other reasons as well. First, access to some of the rights set out in the 1961 Convention and the European Convention on Nationality depends on the recognition of statelessness. Further, statelessness may be relevant in private international law disputes. When determining, for example, which country has jurisdiction over a divorce case, or how property can be inherited, the nationality of the individuals involved may play a role. ${ }^{110}$ Different rules can apply to how one's name is acquired and changed depending on whether one is stateless or a national of a foreign country.111 Statelessness can therefore be legally relevant in various contexts that go beyond the protection norms enshrined in the international treaties on statelessness. It follows that a procedure by which one can establish his or her status of stateless person should not only be open to those who seek legal residence or protection.

For similar reasons, the exclusion grounds of Article 1(2) of the 1954 Convention should not-by contrast to the refugee context and the EU qualification directive-lead to exclusion from the status of stateless person. Whereas the status of refugee has an exclusive meaning in the context of protection, the status of statelessness first and foremost signifies the legal fact of being without a nationality. The issue of whether a stateless person is to be granted protection or residence must be disconnected from the establishment of statelessness. Being a war crimes suspect, or being eligible for protection by other UN agencies than UNHCR, does, and should not, alter the fact of being without a nationality. Therefore, in the context of statelessness determination, the exclusion grounds must be applied with a view to refusing protection and residence to such persons, but without denying recognition of their status. This interpretation is consistent with the wording of Article 1(2) of the 1954 Convention, which excludes certain categories of stateless persons by proclaiming that the Convention 'shall not apply' to them, which does not in any way imply that these persons are not stateless. ${ }^{112}$

\footnotetext{
109 See sections 6.2 and 6.3 below.

110 See, for example, the Dutch Civil Code, book 10 (Burgerlijk Wetboek Boek 10, Internationaal Privaatrecht), art. 16.

111 See, for example, Judgment of the Dutch Council of State (Raad van State) of 23 July 2014, No. 201310945/1/A3 (ECLI:NL:RVS:2014:2760).

112 Although UNHCR has not specifically addressed the issue of exclusion in the statelessness context, the 'Handbook on the Protection of Stateless Persons' indicates that exclusion is only applicable in the context of protection, and not to the establishment of whether a person is to be defined as stateless: UNHCR, Handbook on Protection of Stateless Persons (Geneva, UNHCR, 2014), p. 9, 40.
} 
Member States can be left a margin of discretion in the design and operation of statelessness determination procedures. They may, for example, choose to integrate statelessness determination procedures within the competence of immigration authorities or confer the responsibility for statelessness determination on the organ responsible for nationality matters. ${ }^{113}$ There should, however, be a common interpretation of the definition of statelessness, as well as a minimum set of procedural guarantees and evidentiary standards for determining statelessness. Authoritative guidelines on interpreting the various elements of that definition, procedural guarantees, types of evidence and issues of proof in the context of identifying stateless persons are provided by the UNHCR Handbook on Protection of Stateless Persons. The Handbook may serve as starting point for formulating standards at the EU level. Inspiration may also be drawn from legal arrangements in Member States that already have statelessness determination procedures in place. ${ }^{114}$ Furthermore, the Asylum Procedures Directive (2013/32/EU) can provide useful guidance for setting procedural guarantees.

\subsection{Content of Protection}

The proposed EU mechanism would ensure that individuals with the status of a stateless person are granted a standard of treatment pursuant to the 1954 Convention. Even though not all Member States have ratified the 1954 Convention, there is ample reason to recognize in a Union legal framework that persons who cannot invoke the protection of their country of nationalitybecause they have no such country — should be granted a basic level of civil, social, economic, and cultural rights in their country of habitual residence. The proposed EU framework would provide a modern codification of basic rights to be accorded to stateless persons in the sphere inter alia of social welfare, housing, employment, education, and healthcare. It should also include rights that are specific to stateless persons such as the issue of identity papers and travel documents, and the provision of administrative assistance in relations with foreign States. ${ }^{115}$ The regime of rights and benefits in the Qualification

113 Cf. UnHCR, Handbook on Protection of Stateless Persons (Geneva, UNHCR, 2014), para 63.

114 Good practices have been compiled in: European Network on Statelessness (ENS), Statelessness Determination and the Protection Status of Stateless Persons: A summary guide of good practices and factors to consider when designing national determination and protection mechanisms (London, ENS, 2013). See also Adviescommissie Vreemdelingenzaken (ACVZ), Geen land te bekennen (Dutch Advisory Committee on Migration Affairs, 'No country of one's own') Dec. 2013 (Den Haag, ACvz, 2013), p. 111.

115 Art. 25. 27, and 28 of the 1954 Statelessness Convention. 
Directive $(2011 / 95 / \mathrm{EU})$ can serve as a point of reference. Indeed, in view of the minimal differences in content of protection established under the 1951 Refugee Convention and the 1954 Convention on Stateless Persons, the most practical solution would be to equate the content of protection of stateless persons with that of refugees under the Qualification Directive, except for those rights that specifically address the plight of refugees, i.e. the prohibition of refoulement and protection against penalties for illegal entry.

\subsection{Conditions for Residence}

The 1954 Convention does not entail a right of residence for stateless persons. As we argued above, however, a right of residence is for many stateless persons the only avenue to secure a country of stable residence. Moreover, the absence of a right of residence is problematic in view of the practice in most Member States of making the enjoyment of socioeconomic rights conditional on lawful residence. Union law also presumes that fair treatment needs to be accorded only to legally resident third-country nationals. ${ }^{116}$ In most EU Member States that operate a statelessness determination procedure, including France, Hungary, Spain, and the United Kingdom, statelessness is a conditional ground for a residence permit. ${ }^{117}$ In line with the solution chosen in the EU's asylum regime, this right may initially be temporary and renewable but lead to permanent residence after five years of legal residence. ${ }^{118}$

Statelessness should not, however, in all situations be a ground for residence. First, stateless persons can be excluded from the right to residence based on the exclusion clauses of Article 1(2) of the 1954 Convention. Second, the 1954 Convention allows for the expulsion of stateless persons on grounds of national security and public order. ${ }^{119}$ As in the EU's asylum regime, this may be formulated as a ground for refusing protection and residence, without, however, denying the recognition their status of being without a nationality. ${ }^{120}$ Third, there may be good reason to refuse residence to a stateless person if he has previously enjoyed residence in another country (which can be a third

\footnotetext{
116 See e.g. Art. 79(1) TFEU and Art. 15(3) Charter of Fundamental Rights of the EU.

117 Adviescommissie Vreemdelingenzaken (ACVZ), Geen land te bekennen (Dutch Advisory Committee on Migration Affairs, 'No country of one's own') Dec. 2013 (Den Haag, ACvZ, 2013), pp. 63-67. The Belgian government has announced that the recognition of statelessness will as a rule lead to a grant of temporary residence: Regeerakkoord België 1 December 2011, para 2.7.8.

118 Directive 2011/95/EU, Art. 24; Directive 2011/51/EU.

119 Art. 31(1).

120 Cf. Art. 14(4) Directive 2011/95/EU.
} 
country or another Member State), and if that other country is willing to admit that person and accord him the standard of treatment required by the 1954 Convention. ${ }^{121}$ UNHCR submits that in such cases, the status to be provided can be 'more transitional in nature.'.122 In some Member States where statelessness is a ground for residence, being admissible to the country of former habitual residence is a ground for refusing residence. The Stateless Determination Procedure introduced in 2013 in the United Kingdom includes as a requirement for leave to remain that the applicant 'is not admissible to their country of former habitual residence or any other country.'.23 The additional requirement of 'any other country' is, however, problematic, as it opens up the possibility of removing persons to random countries with which they do not necessarily have a meaningful connection. ${ }^{124}$ It is suggested, therefore, that excludability, public order considerations and being admissible to the country of former habitual residence are included as grounds for refusing a right of residence, without preventing recognition as stateless person.

A further issue is whether States should be compelled to grant residence to individuals who became stateless as a result of voluntary renunciation of nationality. In some States, such persons are excluded from the status of stateless person. ${ }^{125}$ Voluntary renunciation of nationality is, however, not a relevant element in the definition of a stateless person. ${ }^{126}$ Therefore, voluntary renunciation should not play a role at the stage of determination of status, but it may be relevant in examining whether the former country of nationality is willing to reinstate the person's nationality or to admit him on some other basis. ${ }^{127}$ It follows that the question of voluntary renunciation should primarily inform

121 Cf. UNHCR, Handbook on Protection of Stateless Persons (Geneva, UNHCR, 2014), para $153^{-157 .}$

122 Ibid., para 153.

123 United Kingdom Immigration Rules, para 403(c).

124 In the refugee context, the EU Asylum Procedures Directive permits removal to a safe third country only if there is 'a connection between the applicant and the third country concerned on the basis of which it would be reasonable for that person to go to that country': Art. 38(2)(a) Directive 2013/32/EU.

125 See, for example, the statelessness determination procedure in Hungary, Act II of 2007 on the Admission and Right of Residence of Third-Country Nationals, Section 78(1)b.

126 See also UNHCr, Handbook on Protection of Stateless Persons (Geneva, UNHCR, 2014), para 51 .

127 Cf. The Stateless Guidance published by the United Kingdom on 1 May 2013, para. 3.4, which sets forth that ' $\mathrm{t}$ ] here is no obligation to grant leave to remain to those who have become stateless for reasons of personal convenience or choice.' 
the condition of whether a stateless person is not admissible to his country of former habitual residence.

\section{$7 \quad$ Conclusion}

The UN Statelessness Conventions of 1954 and 1961 were adopted out of a profound concern for stateless persons and a sincere desire to assure them the widest possible exercise of human rights. Unlike the 1951 Refugee Convention, however, the statelessness conventions have, to a considerable extent, failed to deliver. Their implementation suffers from quite basic shortcomings, such as the absence of statelessness determination procedures, resistance against granting legal residence, a narrow interpretation of the definition of stateless person and ineffective monitoring and supervision. The increased attention in more recent years for the predicament of stateless people by UNHCR, the Council of Europe, the European Union as well as civil society, has revealed how in the area of the $\mathrm{EU}$, systemic deficiencies hamper the effective protection of stateless persons.

In this contribution, we have explored the potential of the European Union in acting as a bridge between international obligations of Member States and the action needed to implement those obligations. We have submitted that a common EU policy on statelessness would ensure protection as promised by the 1954 Convention, and that it also fits with the Union's objectives of setting common conditions for residence in the EU. The development of such a policy meets the principle of subsidiarity and has a legal basis in the Treaties. Even though there is a certain legislative fatigue in the area of EU migration law, and even though statelessness is not mentioned in the recently adopted strategic guidelines for legislative and operational planning in the area of freedom, security and justice, ${ }^{128}$ developments in the Member States demonstrate that there is now sufficient momentum to initiate legislative action at Union level as well.

128 Conclusions of the European Council of 26/27 June 2014. 